\title{
SOSIAL EKONOMI, KONSUMSI FAST FOOD DAN RIWAYAT OBESITAS SEBAGAI FAKTOR RISIKO OBESITAS REMAJA
}

\author{
Socio-Economic, Fast Food Consumption and Obesity History as A Risk Factors of Adolescent \\ Obesity \\ Rifai Ali ${ }^{1}$, Nuryani ${ }^{2 *}$ \\ ${ }^{1}$ Program Studi Ilmu Kesehatan Masyarakat, Fakultas Kesehatan Masyarakat, Universitas Gorontalo, Jl. AA Wahab Eks (Jenderal \\ Sudirman) No 247, Limboto, Gorontalo, Indonesia \\ ${ }^{2}$ Program Studi Gizi, Fakultas Kesehatan Masyarakat, Universitas Gorontalo, Jl. AA Wahab Eks (Jenderal Sudirnam) No 247, \\ Limboto, Gorontalo, Indonesia \\ E-mail: nuryanigz@gmail.com
}

\begin{abstract}
ABSTRAK
Obesitas merupakan masalah kesehatan masyarakat yang melingkupi hampir seluruh siklus kehidupan termasuk kalangan remaja. Obesitas remaja akan berdampak terhadap peningkatan kejadian obesitas pada masa dewasa serta merupakan salah satu faktor risiko penyakit degeneratif. Untuk menganalisis risiko sosial ekonomi, riwayat obesitas orang tua, pengetahuan remaja dan kebiasaan konsumsi fast food terhadap kejadian obesitas pada remaja. Metode: Jenis penelitian yang digunakan adalah case control study. Penelitian dilaksanakan di beberapa SMA/SMK Kota Gorontalo, dengan jumlah sampel 670 orang remaja, terdiri dari 335 kelompok kasus dan 335 kelompok kontrol. Analisis data dilakukan untuk menilai besar risiko dari variabel independen terhadap kejadian obesitas remaja. Didapatkan bahwa besar risiko pendidikan ayah $(\mathrm{OR}=2,724 ; 95 \% \mathrm{CI} ; 1,970-3,767)$ dan pendidikan ibu yang rendah $(\mathrm{OR}=4,727 ; 95 \%$ $\mathrm{CI} ; 3,357-6,657)$, adanya riwayat obesitas orang tua $(\mathrm{OR}=2,016 ; 95 \% \mathrm{CI} ; 1,482-2,743)$, pengetahuan remaja yang kurang $(\mathrm{OR}=6,673 ; 95 \% \mathrm{CI} ; 2,296-19,393)$ dan konsumsi fast food lebih dari 3 kali per minggu $(\mathrm{OR}=1,829 ; 95 \% \mathrm{CI}$; $1,337-2,502)$ menjadi faktor risiko obesitas remaja, sedangkan pekerjaan ibu sebagai ibu rumah tangga $(\mathrm{OR}=0,338$; $95 \%$ CI; $0,224-0,468)$ merupakan faktor protektif obesitas. Uang saku $(\mathrm{OR}=1,015 ; 95 \% \mathrm{CI} ; 0,724-1,423)$ tidak menjadi faktor risiko obesitas remaja. analisis multivariat menunjukkan pekerjaan ibu merupakan faktor risiko paling dominan dalam memengaruhi kejadian obesitas. Pendidikan orang tua, riwayat obesitas, pengetahuan dan konsumsi fast food merupakan faktor risiko bermakna terhadap kejadian obesitas pada remaja.
\end{abstract}

Kata kunci: fast food, obesitas, pengetahuan, remaja

\section{ABSTRACT}

Obesity is a public health problem that encompasses life cycle including adolescent. Adolescent obesity bring consequences to increase case of obesity in adult and the risk factors for degenerative diseases. This study analyze risk factor of socio-economic, parents history of obesity, nutrition knowledge and fast food consumption with the prevalence of adolescent obesity. The study was case control study and conducted at several high school in Gorontalo City, with 670 adolescent, consisting of 335 case groups and 335 control groups. Data analysis was performed to assess the risk of independent variables of obesity. Low father's education (OR=2.724; 95\% CI; 1.970-3,767), low mother education $(O R=4.727 ; 95 \%$ CI; $3.357-6.657)$, parents history of obesity $(O R=2.016 ; 95 \% C I ; 1.482-2.743)$, low adolescent knowledge $(O R=6.673 ; 95 \%$ CI; $2.296-19.393)$ and fast food consumption more than 3 times per week $(O R=1.829$; $95 \%$ CI; 1.337 - 2.502) increasing the risk of adolescent obesity. Mother occupation as a household mother (OR= 0.338; 95\% CI; 0.224-0.468) become protective factor. Pocket money (OR=1.015; 95\% CI; 0.724-1.423) was not a risk factor of obesity. Multivariate analysis showed that mothers occupation was dominant factor that influence obesity. Parent education, history of obesity, nutrition knowledge and fast food consumption were risk factors for obesity.

Keywords: fast food, obesity, knowledge, adolescent

Rifai A., dan Nuryani. MGI (2018) 123-132

DOI: $10.20473 /$ mgi.v13i2.123-132 


\section{PENDAHULUAN}

Penyakit yang menjadi masalah di Indonesia pada saat ini yaitu penyakit tidak menular baik di kalangan orang dewasa maupun di kalangan remaja. Obesitas adalah hasil dari asupan energi yang tidak diimbangi dengan aktivitas fisik dan dimediasi oleh faktor genetik, perilaku dan lingkungan. Obesitas pada remaja akan meningkatkan risiko obesitas pada usia dewasa dan hal ini juga akan mengarah terhadap peningkatan risiko penyakit kardiovaskular dan sindrom metabolik (Janssen et al., 2004). Hasil penelitian yang dilakukan di Semarang mendapatkan bahwa remaja obesitas sebanyak $80,7 \%$ mengalami sindrom metabolik dan 19,3\% mengalami pra sindrom metabolik (Widyastuti et al., 2016).

Prevalensi overweight dan obesitas meningkat sangat tajam di kawasan Asia Pasifik. Asia Pacific cohort study collaboration (2007) menunjukkan peningkatan pandemi overweight dari $20 \%$ menjadi $40 \%$. Berdasarkan indikator IMT, secara nasional prevalensi overweight $11,5 \%$ dan obesitas $14,8 \%$ untuk orang dewasa di atas 18 tahun, sementara di Provinsi Gorontalo prevalensi overweight 13,7\% dan obesitas $21,0 \%$. Pada remaja usia $16-18$ tahun secara nasional prevalensi overweight adalah 5,7\% dan obesitas 1,6\%, sementara di Provinsi Gorontalo prevalensi overweight pada remaja adalah $7,9 \%$ dan obesitas $2,4 \%$. Secara nasional terjadi tren peningkatan kejadian obesitas pada remaja usia 16-18 tahun yakni $1,4 \%$ pada tahun 2010 meningkat menjadi $7,3 \%$ pada tahun 2013 (Kemenkes RI, 2013). Data Kabupaten/Kota Provinsi Gorontalo pada tahun 2013, menunjukkan prevalensi obesitas pada penduduk dewasa ( $>15$ tahun) yaitu Kabupaten Gorontalo 30,9\%, Kota Gorontalo 36,7\%, Kabupaten Bone Bolango 21,6\%, Kabupaten Boalemo 18,6\%, Kabupaten Pohuwato $14,7 \%$ (Dinkes Provinsi Gorontalo, 2014).

Status sosial ekonomi, pengetahuan tentang obesitas yang rendah, riwayat obesitas orang tua merupakan sejumlah faktor risiko obesitas pada remaja. Penelitian di Pontianak menunjukkan bahwa terdapat hubungan antara status pekerjaan ibu dengan kejadian obesitas pada remaja. Tingginya jumlah uang jajan per hari pada remaja akan meningkatkan risiko obesitas sebesar 2,3 kali
(Rafiony et al., 2015). Penelitian lainnya di wilayah pedesaan Cina menunjukkan terdapat hubungan antara jumlah uang jajan dengan kejadian obesitas pada remaja (Li et al., 2008).

Pengetahuan tentang gizi menentukan perilaku individu dalam mengonsumsi makanan. Hasil penelitian yang dilakukan oleh Wahyuni (2013) mendapatkan adanya hubungan yang signifikan antara riwayat keluarga dengan kejadian obesitas pada remaja. Konsumsi fast food juga diduga sebagai salah satu pemicu obesitas pada remaja. Sebuah penelitian di Semarang menunjukkan bahwa penyebab obesitas yang signifikan dalam penelitian tersebut adalah konsumsi fast food dan kebiasaan mengonsumsi makanan selingan pada remaja (Pramono, 2007). Penelitian di Pontianak menunjukkan prevalensi obesitas remaja $9,2 \%$ dan terdapat hubungan antara asupan energi dari fast food dengan obesitas, akan tetapi tidak terdapat hubungan yang signifikan antara asupan soft drink dengan obesitas (Rafiony et al., 2015). Konsumsi fast food pada remaja kategori sering dan sangat sering berhubungan dengan peningkatan IMT pada remaja (Braithwaite et al., 2014). Penelitian lainnya mendapatkan adanya hubungan negatif antara asupan serat dengan kadar trigliserida darah pada remaja obesitas (Widyastuti et al., 2016). Berdasarkan uraian tersebut diatas, maka penelitian ini bertujuan untuk menganalisis sejumlah faktor risiko kejadian obesitas pada remaja di Kota Gorontalo.

\section{METODE}

Desain penelitian yang digunakan dalam penelitian ini adalah observasional analitik dengan pendekatan case control study yaitu melihat kejadian obesitas pada remaja pada saat ini dan menelusuri riwayat keterpaparan terhadap masing-masing variabel secara retrospektif. Penelitian ini dilaksanakan di sekolah SMA/SMK di Kota Gorontalo Provinsi Gorontalo. Waktu penelitian dilakukan selama 2 bulan. Populasi ditentukan berdasarkan jumlah siswa SMA kelas 1 dan 2 yang ada di Kota Gorontalo. Sampel diambil sejumlah 670 siswa yang terdaftar dan memenuhi kriteria inklusi, dimana didapatkan jumlah sampel kasus 335 orang dan kontrol 335 
orang dengan perbandingan rasio $1: 1$. Sampel yang termasuk dalam kelompok kasus adalah anak yang memiliki status gizi obesitas ( $>1 \mathrm{SD}$ ), dengan kelompok kontrol adalah anak dengan status gizi normal $(\leq 1 \mathrm{SD})$, Analisis data pengukuran status gizi (IMT/U) menggunakan aplikasi $W H O$ Anthroplus.

Penentuan sampel penelitian dengan menggunakan purposive sampling yakni pengambilan sampel penelitian yang memenuhi kriteria inklusi penelitian diantaranya, siswa aktif di sekolah menengah atas atau sekolah menengah kejuruan (SMA/SMK) kota Gorontalo, bersedia menjadi subjek penelitian dan tidak sedang sakit.

Pengumpulan data dilakukan dengan melakukan wawancara, pengukuran berat badan dan tinggi badan pada subjek penelitian. Pengukuran berat badan menggunakan timbangan digital (ketelitian 0,1 kg), sementara pengukuran tinggi badan menggunakan microtoice (ketelitian $0,1 \mathrm{~cm})$.

Pendidikan orang tua, dikategorikan berisiko obesitas jika pendidikan kurang dari 9 tahun, hal ini berdasarkan ketetapan pemerintah tentang wajib sekolah 9 tahun dan pendidikan hingga Sekolah Menengah Atas (9 tahun) sudah dianggap keterpaparan informasi kesehatan pada orang tua lebih mudah diterima. Pekerjaan ibu, dikategorikan berisiko obesitas jika ibu bekerja di luar rumah, hal karena waktu yang digunakan bekerja di luar rumah berbanding terbalik dengan waktu ibu berada di dalam rumah dengan anak remajanya, sehingga tidak dapat melakukan pemantauan gizi pada anaknya.

Variabel pengetahuan gizi dikategorikan berisiko jika pengetahuan tentang obesitas rendah. Variabel uang jajan dikategorikan berisiko jika uang jajan dalam sehari melebihi Rp.15.000, banyaknya uang jajan yang diterima oleh remaja dapat berbanding lurus dengan tingkat konsumsi makanan jajan yang umumnya tinggi kalori.

Riwayat obesitas orang tua dikategorikan berisiko jika salah satu atau kedua orang tua mengalami obesitas. Variabel konsumsi fast food dikategorikan berisiko jika frekuensi konsumsi fast food lebih dari 3 kali dalam seminggu) (Hidayati, 2016). Pengukuran kebiasaan konsumsi fast food menggunakan kuesioner food frequency.
Analisis data di lakukan dengan bantuan komputer dengan menggunakan program SPSS for windows versi 18.0. Analisis data dilakukan secara univariat, bivariat dan multivariat. Analisis univariat bertujuan untuk mendeskripsikan karakteristik tiap variabel penelitian. Analisis bivariat dilakukan terhadap dua variabel yakni variabel obesitas remaja sebagai dependent dan variabel pendidikan, pekerjaan orang tua, pengetahuan remaja, riwayat obesitas, jumlah uang jajan dan konsumsi fast food sebagai variabel independent. Analisis multivariat menggunakan regresi logistik, untuk menilai faktor risiko yang paling dominan dalam memengaruhi obesitas pada remaja. Variabel yang dimasukkan dalam analisis multivariat adalah variabel independent yang signifikan berpengaruh terhadap obesitas remaja pada analisis odds ratio (OR) yakni hasil OR tidak melingkupi nilai 1 pada 95\%CI. Perhitungan odds ratio (OR) digunakan untuk dapat mengetahui estimasi pengaruh dari faktor risiko yang diteliti yaitu sosial ekonomi, riwayat obesitas (genetik), pengetahuan dan konsumsi fast food yang berpengaruh terhadap kejadian obesitas pada remaja di Kota Gorontalo.

\section{HASIL DAN PEMBAHASAN}

Distribusi responden menurut umur di SMA Negeri/SMK Kota Gorontalo pada tabel 1 menunjukan bahwa pada kedua kelompok lebih dari $40 \%$ siswa berusia 16 tahun. Hanya sedikit siswa yang memiliki usia lebih dari 18 tahun.

Tabel 1. Distribusi Karakteristik Remaja Kota Gorontalo

\begin{tabular}{lcccccc}
\hline \multirow{2}{*}{ Karakteristik } & \multicolumn{2}{c}{ Kasus } & \multicolumn{2}{c}{ Kontrol } & \multicolumn{2}{c}{ Total } \\
\cline { 2 - 7 } & $\mathbf{n}$ & $\mathbf{\%}$ & $\mathbf{n}$ & $\mathbf{\%}$ & $\mathbf{n}$ & $\mathbf{\%}$ \\
\hline Umur & & & & & & \\
13 tahun & 1 & 0,3 & 0 & 0,0 & 1 & 0,1 \\
14 tahun & 23 & 6,9 & 20 & 6,0 & 43 & 6,4 \\
15 tahun & 51 & 15,2 & 64 & 19,1 & 115 & 17,2 \\
16 tahun & 140 & 41,8 & 138 & 41,2 & 278 & 41,5 \\
17 tahun & 119 & 35,5 & 93 & 27,8 & 212 & 31,6 \\
18 tahun & 1 & 0,3 & 15 & 4,5 & 16 & 2,4 \\
19 tahun & 0 & 0 & 2 & 0,6 & 2 & 0,3 \\
20 tahun & 0 & 0 & 3 & 0,9 & 3 & 0,4 \\
Jenis Kelamin & & & & & & \\
Laki-laki & 175 & 52,2 & 259 & 77,3 & 434 & 64,8 \\
Perempuan & 160 & 47,8 & 76 & 22,7 & 236 & 35,2 \\
Total & 335 & 50,0 & 335 & 50,0 & 670 & 100 \\
\hline
\end{tabular}


Tabel 2. Sosial Ekonomi, Pengetahuan, Riwayat Orang Tua dan Konsumsi Fast Food serta Kejadian Obesitas pada Remaja di Kota Gorontalo

\begin{tabular}{|c|c|c|c|c|c|c|c|}
\hline \multirow{2}{*}{ Variabel } & \multicolumn{2}{|c|}{ Kasus } & \multicolumn{2}{|c|}{ Kontrol } & \multicolumn{2}{|c|}{ Total } & \multirow{2}{*}{ OR (95\% CI) } \\
\hline & n & $\%$ & $\mathbf{n}$ & $\%$ & $\mathbf{N}$ & $\%$ & \\
\hline \multicolumn{8}{|l|}{ Pendidikan Ayah } \\
\hline$<9$ tahun & 274 & 73,7 & 170 & 50,7 & 417 & 62,2 & $2,724(1,970-3,767)$ \\
\hline$\geq 9$ tahun & 88 & 26,3 & 165 & 49,3 & 253 & 37,8 & \\
\hline \multicolumn{8}{|l|}{ Pendidikan Ibu } \\
\hline$<9$ tahun & 267 & 79,7 & 152 & 45,4 & 419 & 62,5 & $4,727(3,357-6,657)$ \\
\hline$\geq 9$ tahun & 68 & 20,3 & 183 & 54,6 & 251 & 37,5 & \\
\hline \multicolumn{8}{|l|}{ Pekerjaan Ibu } \\
\hline Bekerja & 85 & 25,4 & 168 & 50,1 & 253 & 37,8 & $0,338(0,224-0,468)$ \\
\hline Ibu rumah tangga & 250 & 74,6 & 167 & 49,9 & 417 & 62,2 & \\
\hline \multicolumn{8}{|l|}{ Pengetahuan } \\
\hline Kurang & 25 & 7,5 & 4 & 1,2 & 29 & 4,3 & $6,673(2,296-19,393)$ \\
\hline Cukup & 310 & 92,5 & 331 & 98,8 & 641 & 95,7 & \\
\hline \multicolumn{8}{|l|}{ Uang Saku } \\
\hline$\geq$ Rp. 15.000 & 94 & 28,1 & 93 & 27,8 & 187 & 27,8 & $1,015(0,724-1,423)$ \\
\hline$<$ Rp.15.000 & 241 & 71,9 & 242 & 72,2 & 483 & 72,1 & \\
\hline \multicolumn{8}{|l|}{ Riwayat Orang Tua } \\
\hline Ya & 189 & 56,4 & 131 & 39,1 & 320 & 47,8 & $2,016(1,482-2,743)$ \\
\hline Tidak & 146 & 43,6 & 204 & 60,9 & 350 & 52,2 & \\
\hline \multicolumn{8}{|l|}{ Konsumsi Fast Food } \\
\hline$\geq 3 \mathrm{kali} /$ minggu & 226 & 67,5 & 178 & 53,1 & 404 & 60,3 & $1,829(1,337-2,502)$ \\
\hline$<3 \mathrm{kali} / \mathrm{minggu}$ & 109 & 32,5 & 157 & 46,9 & 226 & 49,7 & \\
\hline
\end{tabular}

Keterangan:

$* \mathrm{OR}$ : odds ratio ${ }^{*} \mathrm{CI}$ : confidence interval $(95 \%)$

Hasil penelitian ini sesuai dengan hasil penelitian Carey et al. (2015) yang mendapatkan bahwa kategori usia remaja yang lebih besar adalah pada rentan usia 15-17 tahun. Rata-rata usia remaja pada penelitian ini masih sesuai dengan kriteria Permendikbud nomor 17 tahun 2017 tentang prasyaratan peserta didik SMA sederajat paling tinggi berusia 21 tahun. Gambaran distribusi responden menurut jenis kelamin menunjukkan bahwa siswa lebih banyak berjenis kelamin laki-laki baik pada kelompok kasus $(52,2 \%)$ maupun kelompok kontrol (77,3\%).

Analisis besar risiko status sosial ekonomi, riwayat obesitas orang tua, pengetahuan dan konsumsi fast food ditunjukkan pada Tabel 2. Hasil penelitian menunjukkan bahwa pada kelompok kasus, sebagian besar $(73,7 \%)$ pendidikan ayah kurang dari 9 tahun atau memiliki risiko tinggi. Pada kelompok kontrol, separuh ayah (50,7\%) memiliki pendidikan kurang dari 9 tahun
$\mathrm{OR}=2,724(95 \% \mathrm{CI}: 1,970-3,767)$, karena nilai selang kepercayaan OR tidak mencakup nilai 1 sehingga dapat dinyatakan bahwa pendidikan ayah merupakan faktor risiko bermakna terhadap kejadian obesitas pada remaja. Pada kelompok kasus, sebagian besar $(79,7 \%)$ ibu berpendidikan kurang dari 9 tahun, sementara di kelompok kontrol lebih dari separuhnya $(54,6 \%)$ berpendidikan lebih dari 9 tahun. Hasil statistik menunjukkan nilai $\mathrm{OR}=4,727$ (95\% CI: 3,357-6,657). Nilai selang kepercayaan OR tidak mencakup nilai 1 sehingga pendidikan ibu merupakan faktor risiko bermakna terhadap kejadian obesitas pada remaja.

Tingkat pendidikan orang tua kurang dari 9 tahun merupakan faktor risiko terhadap kejadian obesitas pada remaja. Pendidikan ayah yang rendah berisiko 2,724 kali lebih besar terhadap kejadian obesitas remaja dibandingkan dengan pendidikan ayah $>9$ tahun. Sementara pendidikan ibu yang rendah berisiko 4,727 kali lebih tinggi terhadap 
kejadian obesitas dibandingkan pendidikan ibu $>9$ tahun. tinggi terhadap kejadian obesitas dibandingkan pendidikan ibu $>9$ tahun.

Penelitian ini sejalan dengan hasil penelitian sebelumnya yang menyatakan bahwa tingkat pendidikan ibu sekolah menengah pertama dan sekolah menengah atas merupakan faktor risiko signifikan terhadap dibandingkan tingkat pendidikan ibu perguruan tinggi (Patsopoulou et al., 2016). Namun, terdapat pula hasil penelitian yang menunjukkan bahwa pendidikan ibu sekolah dasar dan sekolah menengah tidak berpengaruh signifikan terhadap kejadian overweight pada remaja, sementara pendidikan lanjutan ibu memberikan risiko 1,6 kali terhadap kejadian overweight pada remaja (Doustmohammadian et al., 2012).

Hasil penelitian ini juga berbeda dengan hasil penelitian yang terdahulu yang menunjukkan bahwa tidak terdapat hubungan antara pendidikan ayah dan pendidikan ibu dengan kejadian obesitas pada remaja (Rafiony et al., 2015). Sebuah penelitian di beberapa negara yang mengkaji keterkaitan antara pendidikan orang tua dengan kejadian overweight menunjukkan bahwa terdapat hubungan positif antara pendidikan ibu dengan kejadian overweight di Colombia OR=1,90 (95\% CI: $1,23-2,94)$ dan Kenya OR=4,80 (95\% CI: 2,21-10,43), terdapat hubungan negatif antara pendidikan orang tua dengan kejadian overweight di Brazil OR=0,55 (95\% CI: 0,33-0,92) dan Amerika Serikat OR=0,54 (95\% CI: 0,33-0,88) (Muthur et al., 2016).

Tingkat pendidikan orang tua akan berpengaruh terhadap tingkat pengetahuan yang berkaitan dengan kesehatan dan obesitas. Hal ini akan berdampak terhadap perilaku praktek penyediaan makanan, pengawasan aktivitas fisik dan gaya hidup remaja. Tingkat pendidikan ayah akan berpengaruh terhadap aspek penerimaan atau penolakan informasi baru terutama informasi terkait gizi dan kesehatan, sehingga berdampak pada dukungan maupun perhatian yang diberikan pada anak remajanya. Pendidikan orang tua akan berdampak terhadap kualitas dan kuantitas makanan yang dikonsumsi oleh remaja. Adanya perbedaan hasil temuan penelitian dengan sejumlah penelitian terdahulu dapat disebabkan karena karakteristik dasar remaja yang menjadi subjek penelitian serta lokasi penelitian yang berbeda.

Status pekerjaan ibu dikelompokkan menjadi risiko tinggi apabila ibu bekerja di luar rumah seperti pegawai negeri sipil/swasta dan risiko rendah apabila ibu hanya bekerja sebagai ibu rumah tangga. Distribusi responden menurut pekerjaan ibu menunjukkan bahwa pada kelompok kasus, responden yang memiliki risiko tinggi terhadap kejadian obesitas sebanyak 85 remaja $(25,4 \%)$ dan yang berisiko rendah sebanyak 250 responden $(74,6 \%)$, sedangkan pada kelompok kontrol, responden yang memiliki risiko tinggi terhadap kejadian obesitas sebanyak 168 (50,1\%), dan yang berisiko rendah sebanyak 167 responden (49,9\%). Hasil statistik diperoleh nilai $\mathrm{OR}=0,338$ (95\% CI; 0,244-0,468). Nilai selang kepercayaan OR tidak mencakup nilai 1 sehingga dapat dinyatakan bahwa ibu yang bekerja sebagai ibu rumah tangga memberikan efek protektif yang signifikan terhadap kejadian obesitas pada remaja dengan $\mathrm{OR}=0,338$. Hasil penelitian ini didukung oleh penelitian di Pontianak yang menyatakan bahwa terdapat hubungan antara status pekerjaan ibu dengan kejadian obesitas pada remaja (Rafiony et al., 2015). Akan tetapi tidak sesuai dengan hasil penelitian yang menyatakan bahwa pekerjaan ibu tidak signifikan berhubungan dengan kejadian overweight dan obesitas pada remaja Iran (Doustmohammadian et al., 2012). Ibu yang bekerja sebagai ibu rumah tangga dapat lebih fokus dalam memantau perilaku makan, status kesehatan, status gizi dan tingkat aktivitas fisik anak remaja, sehingga peningkatan berat badan secara berlebihan dapat dihindari.

Distribusi responden menurut uang saku menunjukkan bahwa pada sebagian besar responden di kedua kelompok memiliki uang saku kurang dari Rp. 15.000. Nilai OR=1,015 (95\% CI; $0,724-1,423)$. Hasil ini menunjukkan bahwa uang jajan tidak menjadi faktor risiko yang signifikan.

Uang jajan lebih dari Rp.15.000 tidak meningkatkan risiko obesitas remaja $(\mathrm{OR}=1,015$, 95\% Cl;0,742-1,423). Penelitian terdahulu menunjukkan bahwa tingginya jumlah uang jajan per hari pada remaja akan meningkatkan risiko obesitas sebesar 2,3 kali (Rafiony et al., 2015). Penelitian lainnya di wilayah pedesaan Cina juga 
menunjukkan terdapat hubungan antara jumlah uang jajan dengan kejadian obesitas pada remaja, tingginya uang jajan meningkatkan risiko obesitas sebesar 1,9 kali (Li et al., 2008). Jumlah uang jajan berdampak terhadap daya beli makanan dengan kuantitas yang banyak dengan kualitas rendah seperti konsumsi makanan tinggi kalori yang menjadi faktor risiko obesitas. Pada penelitian ini tidak menunjukkan bahwa tingginya uang jajan menjadi faktor risiko obesitas, hal ini dapat disebabkan karena distribusi data uang jajan pada kedua kelompok relatif sama yakni pada kelompok kasus uang jajan kategori risiko tinggi $28,1 \%$ dan pada kelompok kontrol $27,8 \%$. Hanya saja pada penelitian ini tidak mengkaji lebih lanjut distribusi penggunaan uang jajan dan jenis jajanan yang sering dikonsumsi pada kedua kelompok, sehingga belum dapat menguraikan apakah jumlah uang jajan berbanding lurus dengan konsumsi makanan/ jajanan tinggi kalori rendah zat gizi.

Berdasarkan distribusi responden menurut pengetahuan, pada kelompok kasus, responden yang memiliki pengetahuan yang kurang sebanyak 25 remaja $(7,5 \%)$ dan yang berpengetahuan cukup sebanyak 310 remaja (92,5\%). Sedangkan, pada kelompok kontrol responden yang memiliki pengetahuan yang kurang sebanyak 4 remaja $(1,2 \%)$, dan yang berpengetahuan cukup sebanyak 331 remaja $(98,8 \%)$. Hasil statistik diperoleh nilai OR : 6,673 (95\% CI: 2,296-19,393) yang artinya pengetahuan merupakan faktor risiko terjadinya obesitas pada remaja.

Pengetahuan tentang obesitas yang rendah meningkatkan risiko obesitas 6,673 kali pada remaja. Hasil penelitian ini sejalan dengan penelitian terdahulu yang mendapatkan bahwa terdapat perbedaan yang signifikan tingkat pengetahuan terkait penyebab dan risiko kesehatan tentang obesitas antara remaja obesitas dengan remaja dengan status gizi normal di Tirupati India, akan tetapi tidak terdapat perbedaan yang signifikan antara tingkat pengetahuan tentang manajemen dan pencegahan obesitas antara remaja obesitas dengan remaja normal (Jyothi dan Manjuvani, 2015). Tingkat pengetahuan berpengaruh terhadap praktek pola hidup sehat termasuk dalam hal pemilihan makanan dan pemantauan status gizi. Pengetahuan tentang gizi menentukan perilaku individu dalam mengonsumsi makanan. Selain itu remaja dalam memilih makanan dipengaruhi oleh selera dan keinginan remaja terhadap makanan yang cenderung tinggi kalori dan lemak.

Riwayat obesitas orang tua dikategorikan menjadi risiko tinggi apabila salah satu atau kedua orang tua pernah atau mengalami obesitas dan risiko rendah apabila salah satu atau kedua orang tua tidak pernah mengalami obesitas. Berdasarkan distribusi responden menurut riwayat orang tua menunjukkan bahwa pada kelompok kasus, responden yang memiliki risiko tinggi terhadap kejadian obesitas sebanyak 189 remaja (56,4\%),dan yang berisiko rendah sebanyak 146 remaja (43,6\%),sedangkan pada kelompok kontrol, responden yang memiliki risiko tinggi terhadap kejadian obesitas sebanyak 131 remaja $(39,1 \%)$, dan yang berisiko rendah sebanyak 204 remaja $(60,9 \%)$. Hasil statistik diperoleh nilai $\mathrm{OR}=2,016$ (95\% CI; 1,482-2,743) yang artinya riwayat orang tua merupakan faktor risiko terhadap kejadian obesitas remaja.

Riwayat obesitas pada orang tua meningkatkan risiko obesitas 2,016 kali pada remaja. Hasil penelitian ini didukung oleh penelitian yang dilakukan oleh Wahyuni (2013) yang mendapatkan bahwa prevalensi obesitas remaja $26,82 \%$ dari keluarga dengan riwayat obesitas dan terdapat hubungan yang signifikan antara riwayat keluarga dengan kejadian obesitas pada remaja. Penelitian lainnya mendapatkan hubungan antara status obesitas dan overweight ibu dengan kejadian obesitas pada remaja $(\mathrm{p}=0,022 ; \mathrm{RR}=1,76,95 \%$ CI: $1,11-2,08$ dan $\mathrm{p}=0,001$; $\mathrm{RR}=1,78,95 \% \mathrm{CI}$ : 1,28-2,49), sementara itu, tidak terdapat hubungan yang signifikan antara riwayat obesitas dan overweight ayah dengan kejadian obesitas pada remaja ( $\mathrm{p}=0,080$; $\mathrm{RR}=1,49,95 \% \mathrm{CI}$ : $0,95-2,34$ dan $\mathrm{p}=0,903 ; \mathrm{RR}=1,03,95 \% \mathrm{CI}: 0,68-1,56)$ dibandingkan dengan status gizi normal kedua orang tua (Patsopoulou et al., 2016).

Penelitian pada remaja Iran mendapatkan bahwa obesitas dan overweight pada kedua orang tua akan meningkatkan risiko obesitas pada remaja $(\mathrm{p}<0,001, \mathrm{OR}=7,5$ 95\% CI: 5-11,2 dan $\mathrm{p}<0,001, \mathrm{OR}=2,495 \% \mathrm{CI}=1,6-3,6)$ dibandingkan dengan status gizi normal pada kedua orang tua (Doustmohammadian et al., 2012). Remaja yang 
hidup pada lingkungan keluarga yang mengalami obesitas akan cenderung mengalami obesitas akibat adanya pola konsumsi dan pola aktivitas yang hampir sama dengan lingkungan tempat tinggalnya.

Konsumsi fast food dikelompokkan menjadi risiko tinggi obesitas apabila konsumsi fast food $\geq 3$ kali per minggu, sementara risiko rendah apabila kebiasaan konsumsi fast food $<3$ kali per minggu. Berdasarkan distribusi responden menurut konsumsi fast food menunjukkan bahwa pada kelompok kasus, responden yang memiliki risiko tinggi terhadap kejadian obesitas sebanyak 226 remaja (67,5\%),dan yang berisiko rendah sebanyak 109 remaja (32,5\%).Sedangkan, pada kelompok kontrol responden yang memiliki risiko tinggi terhadap kejadian obesitas sebanyak 178 remaja $(53,1 \%)$, dan yang berisiko rendah sebanyak 157 remaja $(46,9 \%)$. Hasil statistik diperoleh nilai $\mathrm{OR}=1,829(95 \% \mathrm{CI} ; 1,337-2,502)$ yang artinya konsumsi fast food merupakan faktor risiko terhadap kejadian obesitas remaja.

Konsumsi fast food dengan frekuensi $\geq$ 3 kali per minggu meningkatkan risiko 1,829 kali terhadap kejadian obesitas remaja. Hasil penelitian ini didukung oleh penelitian terdahulu yang mendapatkan bahwa konsumsi fast food berhubungan dengan kejadian obesitas remaja $(\mathrm{p}=0,014, \mathrm{OR}=2,270,95 \% \mathrm{CI}=1,120-4,640)$ (Rafiony et al., 2015). Penelitian sebelumnya juga menunjukkan bahwa frekuensi konsumsi fast food lebih dari 2 kali per minggu kemungkinan mengalami obesitas 50\% lebih tinggi dibandingkan remaja dengan konsumsi fast food kurang dari dua kali per minggu (Pereira et al., 2005).

Penelitian lainnya yang dilakukan di Semarang menunjukkan hubungan yang signifikan antara konsumsi fast food $(\mathrm{p}=0,048)$ dan kebiasaan jajan $(\mathrm{p}=0,003)$ dengan obesitas pada remaja (Pramono dan Sulchan, 2014). Study cross sectional menunjukkan bahwa konsumsi fast food dengan frekuensi sering, berhubungan dengan peningkatan indeks massa tubuh (IMT) pada remaja (Braithwaite et al., 2014). Terdapat hubungan antara frekuensi kunjungan restoran makanan cepat saji dengan peningkatan IMT pada remaja yakni 4,4\% saat mengabaikan faktor pengaruh teman sebaya, sementara meningkat menjadi $5,11 \%$ dengan pengaruh teman sebaya (Fortin dan Yazbeck, 2015). Prevalensi obesitas meningkat secara konsisten mengikuti peningkatan kunjungan restoran fast food yakni dari 24\% dengan frekuensi 1 kali per minggu hingga 33\% dengan frekuensi kunjungan lebih dari 3 kali per minggu (Anderson et al., 2011). Penelitian yang dilakukan di Makassar mendapatkan hubungan yang signifikan antara asupan energi, asupan lemak dan karbohidrat dengan kejadian obesitas remaja, akan tetapi tidak terdapat hubungan antara fast food dengan kejadian obesitas remaja (Anugrah et al., 2014). Penelitian pada remaja di SMPN 3 Gresik mendapatkan tingkat kecukupan energi yang lebih dari $77 \%$ AKG pada remaja dengan status gizi lebih sebanyak $91,4 \%$ dan yang tidak dapat mencukupi (<77\% AKG) sebesar 9,4\% (Pramudita dan Nadhiroh, 2017). Penelitian lainnya juga mendapatkan bahwa tidak terdapat hubungan yang signifikan antara jumlah dan frekuensi konsumsi fast food dengan kejadian obesitas pada remaja (Inriawati dan Soraya, 2009). Perbedaan hasil penelitian ini dapat disebabkan karena perbedaan karakteristik dasar pada kelompok subjek penelitian dan juga trend kemajuan sebuah wilayah yang berbeda diantara lokasi penelitian.

Frekuensi konsumsi fast food akan memberikan sejumlah risiko ketidakcukupan asupan energi, zat gizi makro dan zat gizi mikro. Fast food merupakan jenis makanan yang dengan kandungan natrium dan lemak jenuh cenderung tinggi yang dapat berdampak buruk terhadap status kesehatan (Sachithananthan, 2015). Penelitian pada remaja putri di Isfahan menunjukkan bahwa tingginya konsumsi fast food secara signifikan menurunkan asupan vitamin B1, fosfor, selenium dan vitamin B12 dibandingkan dengan remaja dengan konsumsi fast food yang rendah. Tingginya konsumsi fast food secara signifikan berhubungan dengan kejadian overweight dan obesitas pada remaja (Rouhani et al., 2012).

Hasil uji regresi logistik pada tabel 3 menunjukkan variabel yang memiliki risiko paling besar adalah pekerjaan ibu. Hasil analisis didapatkan OR dari pekerjaan Ibu adalah 13,04 (95\% CI: 4,445-38,255), yang artinya bahwa remaja yang ibunya bekerja memiliki risiko 13,04 kali lebih besar dari pada ibu yang tidak bekerja. 
Tabel 3. Analisis Multivariat antara Variabel Penelitian dengan Kejadian Obesitas pada Remaja

\begin{tabular}{lcccc}
\hline \multicolumn{1}{c}{ Variabel } & B & OR & $\mathbf{9 5 \%}$ CI & p value \\
\hline Pendidikan ayah & $-0,679$ & 0,507 & $0,185-1,391$ & 0,187 \\
Pendidikan ibu & $-1,116$ & 0,328 & $0,124-0,862$ & 0,024 \\
Pekerjaan ibu & 2,568 & 13,040 & $4,445-38,255$ & 0,000 \\
Pengetahuan & $-1,251$ & 0,286 & $0,032-2,565$ & 0,264 \\
Riwayat orang tua & $-0,907$ & 0,404 & $0,162-1,007$ & 0,052 \\
Konsumsi fast food & 0,040 & 1,040 & $0,410-2,643$ & 0,034 \\
\hline
\end{tabular}

Prevalensi obesitas pada remaja cenderung meningkat dan dapat menjadi sebuah pandemi, apabila tidak dilakukan upaya penanganan yang efektif untuk menekan penyebab obesitas. Tingginya prevalensi obesitas pada negara berkembang dapat disebabkan oleh perubahan gaya hidup dan perilaku makan. Pola makan di daerah perkotaan telah mengalami perubahan dari pola makan yang berbasis tradisional menjadi pola makan western (terutama peningkatan perilaku konsumsi fast food). Transisi perubahan pola makan ini diikuti oleh konsumsi makanan tinggi kalori, lemak, karbohidrat, kolesterol dan natrium tetapi rendah kandungan serat. Hal ini akan berpengaruh terhadap asupan zat gizi yang tidak seimbang yang mengarah terhadap peningkatan risiko obesitas pada remaja (Janssen et al., 2004). Terdapat hubungan negatif antara asupan serat dengan kadar trigliserida darah pada remaja obesitas. Remaja obes berisiko tinggi mengalami sindrom metabolik (Widyastuti et al., 2016). Remaja obesitas juga rentan mengalami gangguan psikologis seperti depresi dan stress, (Masdar et al., 2016).

\section{KESIMPULAN DAN SARAN}

Pendidikan ayah, pendidikan ibu, pengetahuan remaja yang rendah, riwayat obesitas orang tua dan konsumsi fast food merupakan faktor risiko signifikan terhadap obesitas remaja di Kota Gorontalo. Pekerjaan ibu sebagai ibu rumah tangga memberikan efek protektif terhadap obesitas remaja. Analisis multivariat menunjukkan bahwa pekerjaan ibu merupakan faktor risiko paling dominan dalam memengaruhi kejadian obesitas pada remaja. Sebaiknya remaja mengurangi dan membatasi konsumsi fast food. Orang tua remaja disarankan untuk lebih memberikan perhatian terhadap status gizi anak remaja mereka. Bagi sekolah perlu adanya penyuluhan dan pemberian informasi yang lebih intensif kepada siswa mengenai masalah obesitas remaja.

\section{PERSANTUNAN}

Terimakasih kepada pihak Sekolah Menengah Atas (SMA) dan Sekolah Menengah Kejuruan (SMK) yang telah turut berperan dalam pelaksanaan penelitian ini. Teman-teman sejawat di Fakultas Kesehatan Masyarakat Universitas Gorontalo yang telah memberikan arahan pelaksanaan penelitian.

\section{DAFTAR PUSTAKA}

Anderson, B., Rafferty, A.P., Lycon-Callo, S., Fussman, C., \& Imes G. (2011). Fast food consumption and obesity among Michigan adults. Center for disease control and prevention, $8(4), 1-11$.

Anugrah, A.A., Indriasari, R., \& Yustini. (2014) Hubungan konsumsi fast-food dengan kejadian overweight pada remaja di SMA Katolik Cendrawasih Makassar (skripsi tidak dipublikasikan). Universitas Hasanuddin, Makassar.

Asia Pacific Cohort Studies Collaboration. (2007). The burden of overweight and obesity in the Asia-Pacific region. Obes Rev, 8(3), $191-6$.

Braithwaite, I., Stewart, A.W., Hancox, R.J., Beasley, R., Murphy, R., \& Mitchell, E.A. (2014). Fast-food consumption and body mass index in children and adolescents: an international cross-sectional study. Biomed Journal, 4, 1-10.

Carey, F.R., Singh, G.K., Brown, H.I.S., \& Wilkinson, A.V. (2015). Educational outcomes associated with childhoodobesity in the United States: cross-sectional results from the 2011- 
2012 National Survey of Children's Health. International Journal of Behavioral Nutrition Physical Activity, 12 (suppl 1), 1-11.

Dinas Kesehatan Provinsi Gorontalo. (2014). Buku Hasil Riset Kesehatan Dasar Provinsi Gorontalo Tahun 2013. Gorontalo.

Doustmohammadian, A., Abdollahi, M., Bonarianzadeh, D., Houshiarrad A., \& Abtahi M. (2012). Parental determinans of overweight and obesity in Iranian adolescents: A national survey. Iran J Pediatr, 22(1), 35 - 42.

Fortin, B., \& Yazbeck, M. (2015). Peer effect, food consumption and adolescent weight gain. Montreal: Le Cirano.

Hidayati, A.A. (2016). Perbedaan frekuensi konsumsi fast food dan aktivitas fisik pada remaja overweight dan tidak overweight di SMA Nasima Semarang. (publikasi ilmiah). Universitas Muhammadiyah Surakarta. Surakarta.

Inriawati, R., \& Soraya, F. (2009). Hubungan konsumsi makanan cepat saji dan tingkat aktivitas fisik terhadap obesitas pada kelompok usia 11 - 13 tahun. Mutiara medika, 9(2), 121-128.

Janssen, I., Katzmarzyk, P.T., Boyce, W.F., King, M.A., \& Pickett, W. (2004). Overweight and obesity in Canadian adolescents and their associations with dietary habits and physical activity patterns. $J$ Adolesc Health, 35, 360367.

Jyothi, D., \& Manjuvani, E. (2015). Knowledge on overweight among overweight adolescent girls. The Experiment Research Article, 31(4), 2033-2039.

Kemenkes RI. (2013). Riset kesehatan dasar (Riskesdas) 2013. Jakarta, Kementerian Kesehatan RI.

Li, M., Dibley, M.J., Sibbritt, D., \& Yan, H. (2008). Factors associated 33. with adolescents' overweight and obesity at community, school and household levels in Xi' an City, China: results of hierarchical analysis. Eur JClin Nutr, 6(2), 635-43.

Masdar, H., Saputri, P.A., Rosdiana, D., Chnadra, F., \& Darmawi. (2016). Depresi, ansietas dan stress hubungannya dengan obesitas pada remaja. Jurnal Gizi Klinik Indonesia, 12(4), $138-143$.
Muthur, S.K., Onywera, V.O., Tremblay, M.S., Broyles, S.T., Chaput, J.P., Fogelholm, M., Hu, G., Kuriyan, R., Kurpad, A, et al., (2016). Relationships between parental education and overweight with childhood overweight and physical activity in $9-11$ year old children: Results from a 12- country study. Plos One, 11(8), 1-14.

Patsopoulou, A., Tsimtsiou, Z., Katsioulis, A., Rachiotis, G., Malissiova, E., \& Hadjichristodoulou, C. (2016). Prevalence and risk factors of overweight and obesity among adolescents and their parents in Central Greece (FETA project). International Journal of Environmental Research And Public Health, 13 (83), 1-10.

Pereira, M.A., Kartashov, A.I., Ebbeling, C.B., Horn, L., Slattery, M.L., Jacobs, D.R., \& Ludwig, D.S., (2005). Fast food habits, weight gain, and insulin resistance. The Lancet, 365, $36-42$.

Pramono A., (2007). Hubungan antara tingkat aktivitas fisik, kontribusi asupan energy dari fast food dan kebiasaan jajan dengan obesitas pada remaja. KTI Nutrition science program.

Pramono, A., \& Sulchan, M. (2014). Kontribusi makanan jajan dan aktivitas fisik terhadap kejadian obesitas pada remaja di kota Semarang. Jurnal Gizi Indonesia, 2(2), 59-64.

Pramuditas, S.R., \& Nadhiroh, S.R. (2017). Gambaran aktivitas sedentary dan tingkat kecukupan gizi pada remaja gizi lebih dan gizi normal. Media Gizi Indonesia, 12(1), 1-6.

Rafiony, A., PurbFa, M.B., \& Pramantara, I.D.P. (2015). Konsumsi fast food dan soft drink sebagai faktor risiko obesitas pada remaja. Jurnal Gizi Klinik Indonesia, 11(4), 170-178.

Rouhani, M.H., Mirseifinezhad, M., Omrani, N., Esmaillzadeh, A., \& Azadbakh, L., (2012). Fast Food Consumption, Quality of Diet, and Obesity among Isfahanian Adolescent Girls. Journal of Obesity, 1-8.

Sachithananthan, V. (2015). Effect of fast food consumption on the body Mass Index status of Adolescent Girls - A Review. International Journal of Advanced Research in Biological Sciences, 2(3), 20-24.

Wahyuni, S. (2013). Hubungan konsumsi fast food dengan obesitas pada remaja di Akademi 
Kebidanan Muhammadiyah Banda Aceh (Skripsi tidak dipublikasikan). Sekolah Tinggi Ilmu Kesehatan U'budiyah, Banda Aceh.
Widyastuti, N., Dieny, F.F., \& Fitranti, D.Y. (2016). Asupan lemak jenuh dan serat pada remaja obesitas kaitannya dengan sindrom metabolik. Jurnal Gizi Klinik Indonesia, 12(4), 131-137. 